\title{
The harvest and the kingdom: An interpretation of the Sower (Mk 4:3b-8) as a parable of Jesus the Galilean
}

\author{
Author: \\ Ernest van Eck ${ }^{1}$ \\ Affiliation: \\ ${ }^{1}$ Department of New \\ Testament Studies, Faculty \\ of Theology, University of \\ Pretoria, South Africa \\ Note: \\ This article is dedicated to \\ Prof. Dr Johan Buitendag, \\ a friend and colleague, \\ who always has been a \\ voice for the exploited and \\ marginalised of our world, \\ especially in the South \\ African context. \\ Correspondence to: \\ Ernest van Eck \\ Email: \\ ernest.vaneck@up.ac.za \\ Postal address: \\ TPS 15, Box 12320, 0028 \\ Hatfield, South Africa \\ Dates: \\ Received: 07 May 2014 \\ Accepted: 16 June 2014 \\ Published: 20 Nov. 2014 \\ How to cite this article: \\ Van Eck, E., 2014, 'The \\ harvest and the kingdom: An \\ interpretation of the Sower \\ (Mk 4:3b-8) as a parable \\ of Jesus the Galilean', \\ HTS Teologiese Studies/ \\ Theological Studies 70(1), \\ Art. \#2715, 10 pages. http:// \\ dx.doi.org/10.4102/hts. \\ v70i1.2715

\section{Copyright:} \\ C 2014. The Authors. \\ Licensee: AOSIS \\ OpenJournals. This work \\ is licensed under the \\ Creative Commons \\ Attribution License.

This article attempts to read the parable of the Sower (Mk 4:3b-8) as a parable of the historical Jesus. In this reading, the focus is different from almost all previous interpretations of the parable. It is proposed that the Sower should not be understood in terms of realistic agricultural practices in 1st century Palestine, but in terms of the realism of the political, social and economic world in which the parable is told by Jesus. The conclusion reached is that the parable asks its first hearers to align themselves with the kingdom of God, and describes what the results of this decision can be. In a world with little choice, the parable gives a vision on how to cope in an exploitative world.

\section{Introduction}

The interpretation of the parable of the Sower $(\mathrm{Mk} 4: 3 \mathrm{~b}-8)$ has been approached in the past from different perspectives. Apart from its earliest allegorical and theological interpretations, most scholars have focused in the interpretation of the parable on one of its specifics, namely the seed (as the gospel), the sowing (as the proclamation of Jesus), hearing (the different kinds of soil), or the realistic or unrealistic abundant outcome of the harvest, the most prominent interpretation of the parable to be found. An eschatological interpretation of the parable is therefore abundant, whilst only a few scholars have attempted to interpret the parable as a parable of the historical Jesus.

In what follows, an attempt will be made to address this shortfall in the interpretation of the Sower. Firstly, a short description is given of the history of the interpretation of the parable, where after the different extant versions of the parable will be discussed with the aim to identify the most probable earliest version of the Sower (in as far this is possible). Mark's version is proposed as the version of the parable that most probably takes us back to the earliest layer of the historical Jesustradition, and the integrity of Mark's version is discussed. Attention is then given to the realistic aspects of the parable. The argument put forward is that a possible meaning of the parable should not be sought in terms of realistic agricultural practices in 1st century Palestine, but in terms of the realism of the political, social and economic world in which the parable is told by Jesus. Finally, a possible interpretation of the parable is given when read against the political, economic and social realities of 1st century Galilee.

\section{History of interpretation}

The earliest interpretations of the parable of the Sower are the allegorical interpretations of the Church Fathers, ${ }^{1}$ the interpretations from the medieval period, ${ }^{2}$ and the historical and literal (theological) interpretations of Calvin, Maldonatus and Von Harnack ${ }^{3}$. Interestingly, the main foci of the interpretations of Maldonatus (e.g. the different kinds of soil as response or lack of response to hearing the word), Calvin (the sowing of seed as preaching and the fertility of the soil compared to different kinds of hearing), and Von Harnack (the steadily growing of the harvest as symbol for the kingdom) are also the focus of almost all later and recent interpretations of

1.In the interpretation of Irenaeus (Adversus Haereses, IV, xxvi, 1), the field is a reference to the world and the seed hidden in the field a reference to Christ. Augustine (Sermon XXIII; see Kissinger 1979:20) equates the way side, stony ground and thorny places with the 'bad Christians' in the church, and for Chrysostom (Homily XLIV.1; see Kissinger 1979:29) the focus of the parable is the decision to accept Christ or not.

2.Thomas Aquinas (see Bugge 1903:74) sees the parable as a picture of the spiritual life representing a threefold perfection: The seed that yields 30 -fold is the usual or average attainment of perfection, the seed that yield 60 -fold represents the believer who has gone beyond average attainment, and the 100 -fold yield symbolises the believer who has progressed to a stage where a foretaste of ultimate salvation can be experienced. For Bede (in Bugge 1903:37) the seed that do not germinate and bear no or little fruit symbolise the believer who hears a sermon, but because of evil thoughts, evil spirits remove the message from the memory.

3.For Maldonatus (1888:430-435) the parable focuses on the response or lack of response when hearing of God's word. Calvin's interpretation also focuses on the preaching and hearing of the gospel; the preaching of the gospel is like a seed planted and not fruitful everywhere because of the fertility of the soil (see Torrance \& Torrance 1972:79-80). Von Harnack (1901:75) follows more or less the same interpretation: the parable explains how the kingdom steadily grows when the message of Christ comes to the individual and enters the soul by laying hold of it. 
the Sower. Apart from a few interpretations that focus on the parable as a whole, interpreting it either allegorically (i.e. drawing unintended meanings from the parable $)^{4}$ or theologically (i.e. reading the parable in terms of later doctrinal beliefs) $)^{5}$, most scholars focus in their respective interpretations of the parable on one of the specifics in the parable, namely the seed (as the gospel), the sowing (as the proclamation of Jesus), hearing (the different kinds of soil), or the abundant outcome of the harvest.

Scholars, who focus on the parable's depiction of the outcome of the harvest, read the parable as evidence that Jesus' proclamation and understanding of the kingdom was eschatological in content and character. Taking eschatology as cue, Dodd (1961:145-147; see also Westermann 1990:186) typifies the Sower as a parable of growth; the parable illustrates the coming of the kingdom in the ministry of Jesus under the figure of harvest. In the same vein, Schweitzer (1963:36) understands the parable as an illustration of the constant and gradual unfolding of the kingdom, and Weiss (1900:69) identifies the message of the Sower as the hope of the coming of the kingdom of God of which its fulfilment was at hand in the ministry of Jesus. Jeremias's well-known interpretation of the parable also takes as cue the supposed eschatological content of Jesus' proclamation of the kingdom. In the parable, Jeremias argues, the dawn of the kingdom is compared with a harvest that yields of 30-, 60- and 100-fold 'symbolizes the eschatological overflowing of the divine fullness' (Jeremias 1972:150). As such, the parable is an exhortation to converts to examine themselves and test the sincerity of their conversion (Jeremias 1972:79), and assures his disciples that what God has begun in his ministry, despite apparent failure, will have ultimate success. Several scholars have taken up Jeremias's interpretation of the Sower as 'the standard' for its interpretation. According to Schippers (1962:20), Jesus tells the parable to give assurance that the kingdom in future will bear fruit; for Drury (1985:51-52) the parable is a window looking towards the futuristic consummation of the kingdom; Kistemaker (1980:37) identifies the point of the parable as the assurance of an abundant (eschatological) harvest despite the farmer's ups and downs, and Lohfink (2012:108) reads the meaning of the parable as 'the reign of God which is coming'. Crossan (1973:50), like Dodd, typifies the Sower as a parable of growth, and also follows Jeremias's interpretation: the surprise of the advent of the bountiful harvest is suggestive for the futuristic advent of the kingdom. Finally some scholars, although not

4.See, for example, the interpretations of Morgan (1953:40-41) and Dwight (1982:4648). In Morgan's interpretation the field is the world, the seed is the people invited to become part of the kingdom (the hearers), the sowing is the proclamation of the kingdom, and the soil represents the tribulations, persecutions and temptations the people (hearers of the parable) endure. For Dwight, Jesus is sower, the seed is the Word that will be sown throughout the ages, and the different kinds of soil the varying responses to the sowing of the sower, depending on the preparedness of the hearer. See also Boice (1983:15), who also reads the parable as an allegory: the different soils represent the hardened heart, the shallow heart, the strangled heart and the heart open to accept the gospel.

5.Lockyer (1963:174-181), for example, interprets the parable, like Calvin, from a theological perspective. According to Lockyer, the parable is Trinitarian: God, Jesus and the Holy Spirit are the sower of the word (seed), and the soil refers respectively to believers as wayside-hearers, stony soil- or emotional-hearers, thorny soilhearers and good soil-hearers. From this perspective, the parable depicts the hearers and good soil-hearers. From this perspective, the parable
blessed advantages of receiving, understanding and obeying the Word. following Jeremias's interpretations, also comes to the same conclusion regarding the Sower's meaning: Gladden (1883:4), an adherent of the Social Gospel-movement, sees the parable as a description of the orderly development of the kingdom of righteousness in the hearts of men and in the life of society, and Fuchs (1960:428-430), who understands the parables as Sprachereignisse, reads the parable as a reference to the future harvest or the final reckoning.

Scholars, who focus on the seed or act of sowing in the parable, link the act of sowing in the parable with Jesus' activity of preaching in line with the parable's allegorical interpretation in Mark 4:14-20. For these scholars, in short, the sower in the parable is Jesus and the seed is the word (Jesus' message) or the Word (the gospel; see e.g. Boucher 1981:80; Marcus 1986:230; Reid 2001:81; Timmer 1990:24; Tolbert 1989:121-122). Some of these interpretations understand Jesus' preaching within 'the standard' eschatological framework of Jeremias (Guelich 1989:197), whilst others emphasise the failure and/or success of Jesus' ministry of preaching (Boucher 1981:80; Donahue 1988:34; Luz 1990:310; Reid 2001:82; Timmer 1990:24).

When the different kinds of soil is seen as the interpretative key to unlock the meaning of the parable, scholars see the act of hearing and understanding, or the hearing of specific groups, as the focus of the parable. Liebenberg (2000:362-363, $370,375)$, for example, reads the parable as a metaphor; in the parable sowing is preaching which exhorts that listening is understanding (see also Dronsch 2007:304; Flusser 1981:385; Painter 1997:78-81; Weder 1984:110). Several scholars interpret the parable in the same vein: For Snodgrass (2008:152) the parable in nuce is a parable about the hearing the message of the kingdom, whilst others highlight the aspect of hearing and not hearing (see e.g. Baarslag 1940:328; Blomberg 2012:289, 293; Kistemaker 1980:40; Peters 1997:79, 81; Schottroff 2006:67-68; Stiller 2005:36). Some argue that the 'hearing or not hearing'-aspect of the parable is directly addressed to the disciples to encourage them to comprehend the teaching of Jesus (Kilgallen 2008:22-23), to encourage them in spite of their failures (Edwards 2002:138; Jones 1999:195), or to assure them that the kingdom is indeed coming (Barclay 1970:23; Hunter 1960:47; 101-102). ${ }^{6}$

Only a few scholars interpret the parable as a parable of Jesus performed in its original historical context (i.e. not in the literary context of Mark). Cadoux (1930:138) understands the parable as a 'parable of vindication' in which Jesus explains his conduct to his disciples and the multitude and Galston (2012:80-81) sees the parable as a satirical look at horticulture. The sower is a failure, and his failure is a prelude to an average harvest. From this perspective, the point of the parable is to regard the sower with sympathy. Lambrecht

6.Some scholars identify the intended hearers of the parable as the early church or even the Christian believer. According to Hultgren (2000:191), the parable exhorts the church to be faithful in the proclamation of the word that will have surprising, abundant results. Groenewald (1973:28-30) sees the parable as directed to the modern believer who must sow, independent of the reactions of the different kinds modern believer who must sow, independent of the reactions of the different kinds
of soil (believers and non-believers), whilst Jones (1995:299) is of the opinion that the parable warns against all that debilitates Christian presence and mission. 
TABLE 1: Verbal similarities between Mark and Luke and the minor verbal similarities between Matthew and Luke (against Mark).

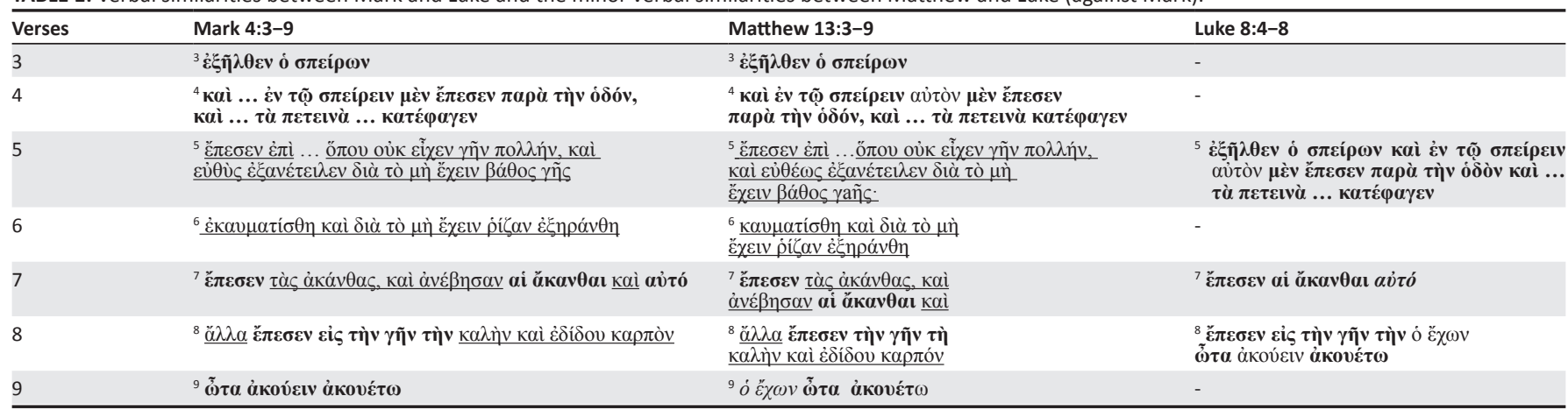

(1983:104) reads the parable as parable of 'contrast and confidence'; in the parable Jesus speaks of himself and his messianic work and gives, notwithstanding many failures and hopeless situations, the assurance of an abundant eschatological harvest.

Finally, a few minority interpretations of the parable can be noted. Scott (1990:361-362) reads the parable as representing the miracle of God's activity; the presence of kingdom lies in failure and everydayness. For Garland (1993:144) the parable explains why Israel rejected Jesus as the Messiah, Wright (1996:230-239) and Garnet (1983:39-54) interprets the seed as the remnant of the true Israel that Jesus is sowing in Israel's own land, and Bowker (1974:115) and Evans (1989:103) see the parable as a midrash on Isaiah 6:9-10. Bultmann (1968:202) and Linnemann (1980:117) find no original intent in the parable; the original meaning of the parable has been lost, and the allegorical interpretation in Mark 4:13-20 is that of the early church.

To summarise: Most of the interpretations of the parable previously discussed focus on some or other individual aspect of the parable, and therefore tend to be 'allegorical'. In what follows it will be argued that a possible meaning of the parable should not be sought in terms of realistic agricultural practices in 1st century Palestine, but in terms of the political, social and economic world in which the parable is told by Jesus. The question that will guide this interpretation is what meaning will come to the fore when the parable is read metaphorically against inter alia the power relations, ownership of land, and taxes and tithes expected from those who worked the land (extracting the so-called 'surplus of the land') in the Galilee of Jesus.

\section{Versions and authenticity}

We have four extant versions of the Sower, ${ }^{7}$ namely Mark 4:3-9, Matthew 13:3-9, Luke 8:4-8 and Thomas 9:1-5. A nearly unanimous consensus exists amongst interpreters of the Sower that Matthew and Luke made use of Mark for their respective versions of the Sower. ${ }^{8}$ That Matthew and Luke are

7.Dronsch (2007:310) also list Agraphon 220, handed down by Abu Hamid alGhazali (a Muslim theologian, jurist, philosopher, and mystic of Persian descent; 450-505 AH/1058-1111 CE), as a possible parallel of the Sower. Except for the clear differences between Agrophon 220 and the extant versions of the Sower (see
Dronsch 2007:311), the mere date of the text disqualifies it as a possible parallel Dronsch $2007: 31$.
of the Sower.

8.The few exceptions to this scholarly consensus are the points of view of Wenham (1974:305), Nolland (1989:377, 382), Luz (1990:237), Funk, Hoover and The Jesus dependent on the Markan version of the parable is clear from the verbal similarities between the three versions, the verbal similarities between Mark and Matthew, the verbal similarities between Mark and Luke, and the minor verbal similarities between Matthew and Luke (against Mark) (Table 1). ${ }^{9}$

There are, of course, also differences between the three Synoptics versions. Mark, for example, refers to the first two seeds planted in the singular (see غ่v $\tau \tilde{\omega}$ $\sigma \pi \varepsilon i ́ p \varepsilon ı v$ in Mk 4:4 and $\alpha 2 \lambda \lambda \mathrm{o}$ in Mk 4:7), to the seeds that fall in the good soil (here Mark uses the plural; see $\alpha 2 \lambda \lambda \alpha$; Mk 8:8) he adds ' $\alpha v \alpha \beta \alpha i v o v \tau \alpha$

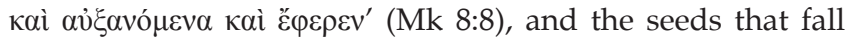
in the good soil produces a yield of 30-, 60- and 100-fold. In Matthew the seeds planted are all referred to in the plural

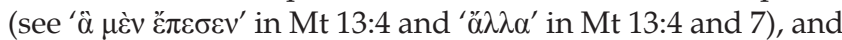
the yield of the seed that fall in the good soil is reported in a reversed Markan order (100-, 60- and 30-fold). Luke has the seed sown on the road trampled on, the second and third seed sown are described as Ë $\varepsilon \varepsilon \rho o v$ (another; Lk 8:6, 7), and the yield of the seed that fell in the good soil produce a yield of 100-fold (Lk 8:8). ${ }^{10}$

In spite of these differences, the verbal similarities between the three Synoptic versions indicate that Matthew and Luke made use of Mark's version. ${ }^{11}$ Mark, therefore, can be considered as the earliest version of the three Synoptics. Also, if one considers the possibility that Mark 4:9 was redactionally added by Mark (see $\S 4$ ), and then taken over by Matthew 13:8 and Luke 8:8, it strengthens the possibility that Matthew and Luke used the Markan version as basis for their respective versions.

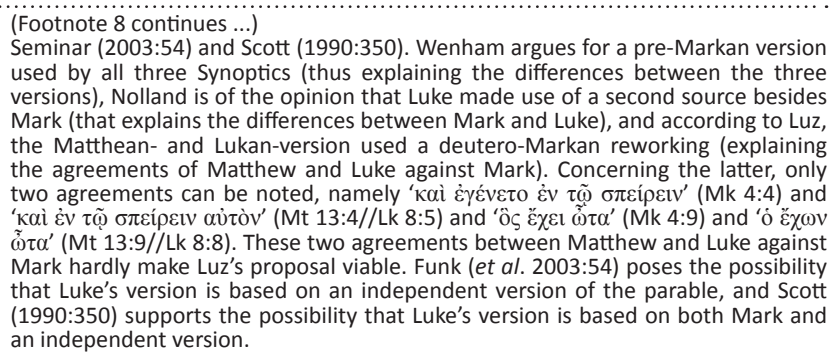

9.In Table 1 the agreements between all three versions are marked in bold, the agreements between Mark and Matthew are underlined, the agreements between Mark and Luke are italicised in bold, and those between Matthew and Luke are italicised.

10.For a detailed description of the differences between the three Synoptic versions of the Sower, see Hultgren (2000:183-185) and Snodgrass (2008:150-151).

11.Also see Marshall (1978:318), Fitzmyer (1985:700) and Hultgren (2000:183) who come to the same conclusion. 
But then what about the Thomasine version? ${ }^{12}$ Most scholars dismiss the Thomasine version of the Sower as the possible earliest or original version of the parable. Marcus (1986:33), Henaut (1993:226-232) and Hultgren (2000:184), for example, see Thomas 9:1-5 as a reworking of Mark, whilst others dismiss the Thomasine version as the earliest form of the parable because of its 'Gnostic' features. ${ }^{13}$

In what follows, Mark's version of the parable is considered as the extant version closest to the layer of the historical Jesustradition. The original structure of the parable most probably was triadic (three instances of sowing and failure, consisting of three phrases each, contrasted with three successful yields), and is the best preserved by Mark. Mark also left the probable original conclusion of the parable unaltered (Funk et al. 1993:54). ${ }^{14}$ The repeated Semitism in Mark 4:7 (кoì

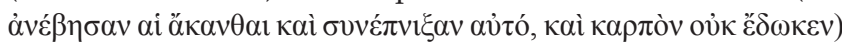

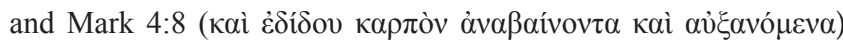
also seems to point to Mark most probably being the earliest version we have (see Crossan 1973:43).

Most scholars, in their respective interpretations of the parable, simply assume that the Sower is an authentic parable of the historical Jesus, whilst others explicitly state its authenticity, albeit for different reasons. For Scott (1990:350), 'Mark's thirty, sixty and hundredfold lack both symmetry and logical closure', and thus the parable is most probably authentic. Crossan (1973:43) emphasises the paratactic nature of the parable and the folkloric contrast between three varying degrees of wasted seed (road, rocks and thorns) and three varying degrees of fruitful seed (30,60 and 100) which, according to him, indicates authenticity. Boucher (1981:80) sees the realism of the parable (e.g. the method of sowing and sowing that precedes ploughing), as well as the language of the parable that shows traces of an Aramaic original, as signs of authenticity (see also Lambrecht 1983:98). Hultgren

12.Funk, Hoover and The Jesus Seminar (2003:478) translation of Thomas 9:1-5 from the Coptic reads as follows: 'Jesus said, Look the sower went out, took a handful (of the Coptic reads as foll (them). Some fell on the road; the birds cant seeds), and scattered (them). Some fell on the road; the birds came and gathere . heads of grain. Others fell on thorns and them. And others fell on good soil, and it produced a good crop: it yielded sixty pe measure and one hundred twenty per measure.'

13.According to Crossan (1973:42-44), the Thomasine-version 'read and understood the parable] as depicting the failures and successes of true gnosis'. Kistemake $(1980: 237$, n. 20) sees the 'Gnostic mold' of the parable in Thomas 9 in the 120 -fold that is yielded by the seed sown in good soil. In his opinion, the number 120 was seen by Gnostics as the number of perfection. Blomberg (2012:288), in following Schrage, depicts Thomas 9:1-5 as a free Gnostic interpretation of Mark, and Peters (1997:70-71) interprets the expression 'up to heaven' in Thomas 9:3 and 5 as reflecting the 'gnostic conceptual framework of the document'. This interpretation of Peters is based on the translation of Thomas from the Coptic by Messrs. Brill of of Peters is based on the translation of Thomas from the Coptic by Messrs. Brill of Leiden, which reads as follows: 'Jesus said: Behold, the sower went forth, he fille his hand, he cast. Some fell upon the road; the birds came and gathered them. Others fell on the rock, and sent no root down to the earth nor did they sprout any ear up to heaven. And others fell on the thorns; they choked the seed, and the worm ate them. And others fell on the good earth, and brought forth good fruit unto heaven, some sixty-fold and some an hundred and twenty-fold' (translation viewed on 10 March 2014, from http://www.goodnewsinc.net/othbooks/thomas. html). Recently Patterson, Bethge and Robinson (2011) have argued convincingly that Thomas is not Gnostic. Patterson et al. (2011:33-38) date the gospel of Thomas in the last decades of the 1st century, and places the sayings collection in Thomas within the well-used genre of ancient literature known as logoi sophon (sayings of the wise; Patterson et al. 2011:41). Rather than being Gnostic, Thomas is one of the earlier attempts to read the Jesus-tradition through the lens of Middle Platonism (Patterson et al. 2011:47).

14.Interestingly, this position of Funk et al. (1993) is contradicted in their discussion of Thomas 9 , where they state that 'Thomas has preserved ... the form of the parable of the sower that is closest to the original (see Funk et al. 1993:479). Also confusing is the that is closest to the orisine (see yields were probably thirty, sixty, one hundred, as Mark records them, although the doubling of sixty to one hundred and twenty may have been original' (Funk et al. 1993:478).
(2008:189) interprets the abundance of Semitisms in the Sower as mark of authenticity, and for Marcus (2000:294) the agricultural motive and obscurity point to authenticity. Finally, scholars like Klauck (1978:1978) and Brouwer (1946:140), who reads the parable through an eschatological lens, also deem the parable to be authentic. According to Klauck, the eschatological slant in the parable fits only with Jesus, and Brouwer argues that in the parable Jesus, by proclaiming God's rule, is also establishing it, an aspect of Jesus' ministry that he argues is typical of Jesus. Only a few scholars see the parable as not coming from Jesus. Drury (1985:55), because of the parable's interpretation in Mark 4:13-20, reads the parable as a Markan creation, and Carlston $(1975: 148)$ renders the parable not authentic because, in his opinion, Jesus was not concerned about people's hearts.

\section{Integrity}

The structure of Mark 4:1-34, of which the Sower is part of, is a Markan construct. The redactional hand of Mark in constructing this narrative unit is well documented by several scholars. ${ }^{15}$ In delimiting the Sower, as one of the narratives that make up Mark 4:1-34, the following are important. Firstly, it is clear that Mark $4: 1-2^{16}$ serves as introduction (and geographical setting beside the sea for the teaching in the narrative) for the larger narrative, with Mark 4:33-34 as its conclusion. Secondly, Mark 4:10 and Mark 4:33-34 links with Mark 4:2 as structural markers in the larger narrative; in Mark 4:2 Jesus begins to teach in parables, in Mark 4:10 those around him ask him about the parables, and in Mark 4:33-34 it is stated that Jesus only taught in parables as those present were able to hear it (which links with Mark 4:11-12). ${ }^{17}$ Mark 4:10-34 also seems to be redactionally inserted between Mark 4:9 and Mark 4:35 (Snodgrass 2008:152). From this it is clear that the Sower can be identified as a narrative unit consisting of Mark 4:3-9.

Mark starts the parable of the Sower in Mark 4:3a (as a second introduction to the parable) with Aкоvєєє; (Listen!), the only time a parable of Jesus is introduced in this manner (see Hultgren 2000:190). Mark 4:3a is thus most probably redactional. This possibility is confirmed when in Mark 4:9, which serves as conclusion to the parable, hearing again is the focus. Hearing is also referred to in Mark 4:12, also as conclusion to the logion in Mark 4:11-12. The parable proper thus can be delimited to Mark 4:3b-8.

With regards to the integrity of Mark 4:3b-8, Peters (1997:72) is correct that, given that the exact content of the pre-Markan version of the parable is not known to us, 'it is unproductive to speculate on possible Markan modifications to the tradition'. Important here is that Mark 4:3a-8 has a triadic

15.Some scholars identify a five part chiasmus in Mark 4:1-34, namely A (Mk 4:12a), B (Mk 4:2b-20), C (Mk 4:21-25), B́ (Mk 4:26-32) and Á (Mk 4:33-34; see e.g. Dewey 1980:150; Lambrecht 1983:86-87), whilst others like Snodgrass (2008:157) and Donahue (1988:29) identify a seven-part chiasmus, demarcated as A (Mk $4: 1-2)$, B (Mk 4:3-9), C (Mk 4:10-12), D (Mk 4:13-20), Ć (Mk 4:21-25), B (Mk $4: 26-32$ ) and Á (Mk 4:33-34). See also Jeremias (1972:13-18) for a discussion of the possible pre-Markan traditions used by Mark to construct Mark 4:1-34.

16.See Lambrecht (1983:90) for a discussion on why Mark 4:1-2 is certainly from Mark himself.

17.Jeremias (1972:15) considers Mark 4:11-12 as pre-Markan ('a very early tradition'), stemming from a Palestinian tradition. 
structure (three sections in which the seed fails, each section consisting of three phrases, contrasted with three levels of success; characteristic of oral discourse (Funk et al. 1993:54). It can thus, in following Peters (1997:72), be concluded that 'the pre-Markan tradition, utilised by Mark and inherited by Matthew and Luke, was very similar to what we have in Mark 4:3b-8'. For the interpretation of the Sower to follow, Mark 4:3b-8 therefore will be considered as the version of the parable closest to the layer of the historical Jesus-tradition with its integrity intact.

\section{Agriculture and realism in the 1st century}

In finding a possible meaning of the parable, it is commonplace for interpreters to make use of agricultural arguments to render the parable as a realistic representation of agricultural practices in 1st century Palestine. When realism is the topic, two aspects of the Sower are discussed, namely the sowing of the sower, and the size of the yield.

The sowing of the sower, as described in the parable, is seen by the majority of interpreters as a realistic portrayal of ancient farming practise in 1st century Palestine (see Blomberg 2004:106; Boucher 1981:80; Dwight 1982:46; Hunter 1960:17; Kistemaker 1980:31; Linnemann 1980:115; Scott 1990:352-353; Snodgrass 2008:166-167; Stein 1981:36-37). These scholars' understanding of the realism of the parable is based on the opinion of Jeremias (in following Dalman; see Jeremias 1972:11) that in 1st century Palestine sowing preceded ploughing. This practise means that the sower was not careless, reckless or clumsy; he simply sowed in a way that was normal practise. This point of view of Jeremias has sparked a meaningless debate about the realism and possible meaning of the parable. White (1964:300-307) and Jeremias (1966:48-53) questioned this sequence (arguing for ploughing and then sowing; see also Drury 1985:56-57; Hultgren 2000:187), and Payne (1978:123-129) took up the debate by arguing for both sequences, depending on the season in which the sowing took place.

The yield described in Mark 4:8 also has attracted too much attention in the history of the interpretation of the parable. Is the size of the yield (30-, 60- and 100-fold) realistic or not? In addition, is Mark describing the yield of individual seeds or the yield of the harvest? Several points of view exist amongst scholars regarding these two questions. Those who understand the yield described in Mark 4:8 as referring to the yield of individual seeds see the yield as normal (indeed prosperous but not exaggerated; see Hedrick 2004:43; Linnemann 1980:117; McIver 1994:606-608; Oakman 1986:63-64; Schottroff 2006:73; Scott 1990:357; Snodgrass 2008:155), whilst others deem the yield as extraordinary and impossible (Hultgren 2000:187), a typical example of parabolic hyperbole (Malina \& Rohrbaugh 2003:160; Stiller 2005:39), or an exaggerated figure to emphasise the contrast between the first three soils and the last one (Blomberg 2004:106, 2012:289). ${ }^{18}$
In the following section it will be argued that the parable indeed is realistic. The realism of the parable, however, should not be sought in the parable, but behind the parable. Put differently, 1st century agricultural aspects and practices should not be the focus, but rather the realism of the world in which the parable is told.

\section{The political, social and economic realities behind the parable of the sower}

In 63 BCE, after Rome's initial conquest of Judea, Galilee and other parts of Palestine, the Romans laid the Judeans and Galileans under tribute. During the reigns of the client kings of Rome, Herod the Great (37-4 BCE) and Herod Antipas (4 BCE-39 CE) in collaboration with the Herodians ${ }^{20}$ (the new elite and retainer classes, replacing the old Hasmoneans), ruled and taxed Judaea and Galilee. ${ }^{21}$ The tribute and

(Footnote 18 continues ...)

fell in good soil in a different way than other interpreters. In his opinion, what is involved here is what is called 'stocking'; when grain germinates it first produce only one shoot. At an early stage of the germinating process, the lowermost nodes also push outside shoots that cause the main stem to branch out beneath the earth. Given that the normal of grains per ear is more or less 30, the 30-, 60- and 100 -fold simply means that in the first case there was no stocking, in the second case a stocking of two stems took place, and for the 100-fold yield there was a stocking of three stems. The yield described in the parable is thus realistic.

19.The framework of the following discussion of the political, social and economic realities that can be considered as the backdrop of the Sower is based on the work of Horsley (1966:29-36, 2009:81-91).

20.The elites, especially Herodians, legitimated their taxing of the of the peasantry through the claim that the ownership and use of land, the flow of goods and the demands for any surplus that might accrue 'corresponded to the natural order of things: the annual tribute to the emperor and the agricultural and other offerings for the temple ensured that the highest authority's claims were clearly established, and as the immediate representatives of this twin authority, client rulers and Jerusalem priests, were entitled to their share by association' (Freyne 2004:1819). Cities, according to Sawicki (2000:115), enabled the Romans to 'interrupt the traditional local cycles of production and consumption'.

21.According to Josephus (Ant. 14.202-203), Rome required a quarter of the harvest every second year (roughly $12.5 \%$ per year). Soon after Herod the Great was appointed as military governor of Galilee in $47 \mathrm{BCE}$, he extorted a hundred talent allotment from the Galileans. During his reign, Herod the Great, who was famous for his tight economic control and administration skills (Freyne 1980:190, increased demands for royal taxes and improved the efficiency of tax collection. Apart from the 900 talents Herod the Great had to pay to Caesar, the laographia (or tributum capitis) was also levied, at a rate of one denarius per head per year, as well as taxes on houses (Josephus, Ant. 19.229), sales (Josephus, Ant. 18.90), internal tolls and customs (see Applebaum 1977:373-374; Sawicki 2000:114). These taxes, according to those who opposed Archelaus before Augustus in becoming king after the death of Herod the Great, 'filled the nation full of poverty' (Josephus, J.W. 2.86). According to Josephus (J.W. 2.386), the total annual revenue paid by Judea was the equivalent of the revenue obtained from Egypt in a month. According to Strabo (Geography XVII.798) that Ptolemy Auletes's income was 13 500 talents, which would mean an annual Judean revenue of some 1000 talents (see Applebaum 1977:375). This number compares well with Josephus's statement that Herod's yearly income just before his death amounted to somewhat over 900 talents (see Josephus, Ant. 17.318-320). Applebaum (1977:373) gives the following description of the taxation of the peasantry under Herod the Great: 'It is to be assumed, accordingly, that Herod's subjects had both to pay tribute to Rome and to cover the King's enormous expenditure on his ambitious programme of urbanization and building, as well as the cost of his elaborate administration and the numerous grants that he made to his friends and to Greek cities outside Judaea. This burden, moreover, came alter twenty years of destructive warfare, and a series of arbitrary and oppressive monetary exactions imposed by a succession of Roman potentates, including Antony himself'. Although Antipas's estimated private income from his territories was less than a quarter of that of Herod the Great (200 talents; see Josephus, Ant. 17.318; J.W. 2.95), most peasants were exploited to such a level that they barely lived at a level of subsistence. This amount of money was raised in part through land taxes both from Antipas's private leased estates and from private holdings, and in part from tolls and customs taxes. 'In all probability there was the Roman tribute too, which would have equalled the amount of private revenue, though we have no direct information on the matter' (Freyne 1980:191-192). 
taxes extracted from the peasantry came from the so-called 'surplus of the harvest' (a 'euphemism for goods and labor that previously had been tied up the village level'; Sawicki 2000:115). Herod Antipas, the first Roman client ruler who resided in Galilee, ${ }^{22}$ implemented a 'policy of urbanization, establishing cities as a way of controlling and exploiting the countryside' (Horsley 2009:87). ${ }^{23}$ Under the Herods, the Galilean peasantry was burdened by at least three levels of taxation: the Roman tribute, taxes to Herod, and the tithes ${ }^{24}$ and offerings ${ }^{25}$ demanded by the high priesthood situated at the Temple in Jerusalem, the centralised economic institution that dominated the economy of Judea. Added to this, in some cases, were rents. According to Hopkins (2002:204), the largest portion of extraction was not tribute and taxes (which made up less than a percent of a crop), but rents paid on leased land confiscated by the aristocracy. These rents, that could make up $50 \%-60 \%$ of a crop, had to be paid to absentee landlords who rented large pieces of land of occupied land (see Hopkins 2002:204-208).

For the Galileans, these were difficult times. Periodic warfare, enslavement, lean years, ${ }^{26}$ and the extra economic burden placed on them by Roman tribute, rents, special levies of taxes over and above the dues already paid to the Hasmoneans, made survival difficult; peasant farmers battled for survival, and village communities began to disintegrate. ${ }^{27}$ If one adds to these religious dues and the provision of seeds for the following season, at best mere subsistence farming was all that was possible (Freyne 1980:186). Peasant farmers fell into debt, 'often to Herodian officials who controlled stores of food' (Horsley 2009:89). The Roman and Herodian elite, as well as the temple aristocracy, used this dire situation of the peasantry to enhance their income by exploiting the peasant's need to pay the expected tribute, taxes, rents and tithes (Applebaum 1977:370). The Herodian elite and temple aristocracy, using the surplus of funds created by resources coming from Diaspora communities (temple tax) and from

22. When Antipas was appointed in 4 BCE, Judea (along with Samaria and Idumea) was placed under the command of a Roman military governor. This political situation was new to the Galileans and the priestly rulers in Jerusalem who now no longer had direct jurisdiction over Galilee. The priestly aristocracy in Judea - who was responsible for charging and delivering the royal tribute - and Antipas now competed for influence and revenues from the Galilean peasantry.

23. Antipas rebuilt Sepphoris (known as the 'ornament of Galilee') from where the peasant farmers and Galilee were taxed, and in $17 \mathrm{CE}$ built Tiberias (in honour of the new emperor Tiberius) to administer the taxation of the fishing industry around the Sea of Galilee.

24.Priestly caste status carried the right to agricultural tithes. This was a steady income for the priestly elite 'sheltered from Roman taxation and protected from erosion by inflation of the coinage' (Sawicki 2000:125).

25.The offerings that was due to the temple inter alia included the terumah (a heave offering), a specific portion of the harvest (one-fortieth to one eightieth) which had to be given to the priests (Freyne 1980:278).

26.Josephus has a number of references to instances when bad harvests created physical hardship and economic disaster for the peasantry (see Ant. 14.28; 15:299$303,365 ; 16: 64 ; 18: 8 ; 20: 101)$.

27.This changing economic situation of the peasantry also brought about a change of values amongst the ever-increasing group of deprived and exploited small landowners. The system of tithes and other agricultural offerings that had been devised to underline Yahweh's ultimate ownership of the land and a mode of production based on trust in Yahweh's seasonal blessings to Israel, was replaced by 'one driven by greed, opulence and exploitation, inevitably fractured the tenuous connection between land, people and religious concerns. Elites, on the other hand, had no particular attachment to the land other than to exploit its resources to the had no particular attachment to the land other than to exploit its resou
maximum, literally and metaphorically draining it' (Freyne 2004:46). local revenues such as rents and tithes, made loans ${ }^{28}$ (with and interest rate up to $20 \%$ ) to peasants in debt who struggled to survive and feed their families after meeting their obligations for tribute, tithes, offerings and sacrifices. The income accumulated from these loans not only increased the wealth of the elite, but also enabled them to foreclose on loans that could not be paid. Normally, this meant that peasants lost their land. Archaeological evidence and passages in Josephus indicate that during Antipas' reign more and more of the land in the Judean hill country was transformed into large estates owned by absentee landlords and worked by tenants, who most probably worked the land they previously owned ${ }^{29}$, and day labourers (who most probably also lost their land). When it is taken into consideration that the great plain just south of Galilee had long become royal land (owned by the Herodian elite or retired Roman soldiers), it is clear that less and less land in Judea belonged to the peasantry. ${ }^{30}$

In Galilee the situation was the same; whilst most of the peasantry still lived on their ancestral inherited land, spiralling debt was only a step away from the loss of land (Horsley 2009:91). It also seems that most of the cultivatable land in Galilee was owned by the elite, as recent research on the Parables of Enoch (1 En 37-71), written in Galilee ${ }^{31}$ in the time of Herod the Great or in the early decades of the 1st century $^{32}$, indicates (see Aviam 2013:159-169; Charlesworth 2013:35-57). In the Parables of Enoch there are several references to the future judgement and punishment of the sinners', the 'chosen ones', the 'strong', the 'kings of the

28.The mention of the trapezai (moneychangers) and archeai (moneylenders) at Sepphoris are evidence of the harsh realities of peasant economics in Galilee (Freyne 1980:181).

29.Many tenants, who originally may have been owners of their own plots, in a bad year most probably bartered their land in order to pay tribute, taxes and tithes, feed their families or buy grain for the following season. 'Once that had happened there was never any possibility of their retrieving the situation, and they were fortunate indeed if they could survive as tenants on what was formerly their own land' (Freyne 1980:195)

30.According to Applebaum (1977:373-374), several factors contributed to a considerable increase of the tenant class in Judaea in the Herodian period. The displacement of Jewish population from the coastal plain and Transjordan under Pompey converted large numbers of Jewish cultivators into landless labourers. In addition to this, Herod's numerous confiscations of the property of his political addition to this, Herod's numerous confiscations of the property of his political
opponents (e.g. the Hasmoneans, see Josephus, Ant. 16.155; 17.147, 305-307) must have increased the areas of royal-owned land. The owners of these large rural properties most probably were 'the councillors and upper religious hierarchy in Jerusalem', and elites residing in other urban centres (Applebaum 1977:372) Herod Antipas owned private estates in the region he built his new city Tiberias (Josephus, Ant. 18:37). He most probably also owned estates in the region of Sepphoris (Freyne 1980:165). No direct information is available on Herod the Great's handling of the land situation in Galilee, but it can be presumed that the pattern was similar to other parts of the country; 'the best lands became part of the royal possessions, either through confiscation or because their owners could not meet the heavy taxes which Herod exacted from the country people' (Freyne 1980:164).

31.This provenance for 1 Enoch $37-71$ is based on the Jewish character of the book of the Parables, the description of the elite owing the land, and the peasantry (previous landlords) demoted to tenant farmers. As put by Charlesworth (2013:53): 'Most scholars will have little difficulty in perceiving that the Parables of Enoch is an anti-Herodian polemic'. Aviam (2013:159-169) is even more specific in postulating a provenance for the. Based on the geographical references in 1 Enoch 6.6 and 13.7, the botanical references in 1 Enoch 19.19, 24.4, 31.2 and 32.4 and the historical reference in 1 Enoch 56.5 that connects with the geographical references in 1 Enoch 46.8, Aviam suggests Migdal in Lower Galilee as place of writing 1 Enoch $37-71$.

32.Charlesworth (2013:43-48) bases this dating of the Parables of Enoch on five arguments: The insignificance of the fact that no fragment of 1 Enoch has been identified amongst the fragments found in the Qumran caves, the late composition of the Parables of Enoch within 1 Enoch in Galilee, the fact that it was not composed in Qumran, the curse on the landowners in 1 Enoch 62, and the reference to the Parthian invasion in 1 Enoch 56. This invasion, described by Josephus in his Antiquities 14.333-344, ended in 40 BCE, the same year in which Josephus in his Antiquities 14.333-344, ended in 40 BCE, the same year in which
Herod was declared by the Roman Senate as 'king of the Jews' (see Charlesworth 2013:43, 47). 
earth; and the 'mighty' who possess the 'dry land' or 'the earth' (see 1 En 38.1, 3-5; 40.8; 41.2, 8; 45.2, 5; 46.4-6; 48.8; $53.2 ; 54.1-2 ; 55.4 ; 62.1-6,9 ; 63.1-10 ; 63.12 ; 67.8)$. Based on the cursing of kings in texts such as 1 Kings 21:10 and 13, Isaiah 8:21 and Ecclesiastics 10:20, and rulers in Exodus 22:28, Leviticus 4:22 and Proverbs 28:15, the kings of the earth referred to in 1 Enoch clearly denote the Roman emperors (Charlesworth 2013:48). The 'dry land', Charlesworth (2013:49) argues, refers to the cultivatable land near wet areas of swamps, which was situated in vast areas west of the Kinneret, the low country near the coast, and in the Hulah Valley. Charlesworth (2013:49) continues: 'The author of the Parables of Enoch laments that he and other Jews labour on such land, whilst the strong, the sinners, 'eat of the produce of such land.' According to 1 Enoch 62, these sinners are 'the kings, the governors, the high officials, and the landlords' (1 En 62.1, 3, 6); they are those who 'eat all the produce of crime' (1 En 53.2) and whose deeds are criminal (1 En 53.2) and oppressive (1 En 54.62). The oppressed, on the other hand, long to rise, eat and rest (1 En 62:14). In the end, however, the governors, the high officials, and the landlords will not be saved by their gold and silver (1 En 53.28). Clearly, this picture depicts the situation in Galilee in the time of the Herods.

From this it is clear that, also in Galilee, vast amounts of cultivatable land was owned by the elite and worked by the peasantry to the benefit of kings, governors, high officials and landlords; a picture that fits the description of the political, social and economic situation in Galilee in 1st century Palestine as described previously. Galilee thus did not escape the advancing aggrandisement of the Herodian dynasty as more and more of the best lands of Palestine fell into the hands of the ruling elite..$^{33}$

The many silos containing grain for the Roman tribute found in upper Galilee (in Gischala; see Josephus, Life 71), in the south at Beth Shearim (Josephus, Life 118-119), as well as the vaults in the lower city of Sepphoris, are evidence of the economic structure in which Rome demanded and the peasant farmers rendered up tribute and taxes. ${ }^{34}$ In cases where tax, tribute and rents were paid in kind, roads were needed to transport these goods, and where taxes or rents were exacted in money, peasants had to make use of available roads to transport their goods to local markets to sell to wholesale merchants (Hopkins 2002:209). Very soon after being appointed as client king of Rome in Judaea, Herod the Great build a port, Caesarea-Maritima, as well as roads to support trade and the transport of goods (e.g. wheat) to Rome. According to Sawicki (2000:31, 112), roads had networked Galilee from time immemorial to support this flow of goods. The covert

33. Applebaum (1977:378) summarises the situation of the peasantry at the beginnin of the 1st century as follows: '[T] he Jewish peasant at the end of the last century $\mathrm{BC}$ was suffering the effects of expropriation from the coastal plain, Samaria and Transjordan; he had been afflicted by a succession of wars and arbitrary impositions, was desperately short of land and reserve capital, and continued to experience gruelling taxation coupled, where a considerable section of his class was concerned, with an oppressive and humiliating tenurial regime exacerbated by debt and the non-Jewish or pro-Roman attitude of its administrators and landlords.

34.See the parable of the Rich Fool (Lk 12:16-20), that depicts such storage capacity. function of these roads was to siphon wealth off and out of the land. As such, roads symbolised occupation, economic pressure and the exploitation of the peasantry who produced the goods that were transported on these roads (see Sawicki 2000:117-118, 132, 178).

Applebaum (1977) summarises the situation of the peasantry at the beginning of the 1st century as follows:

[T] he Jewish peasant at the end of the last century BC was suffering the effects of expropriation from the coastal plain, Samaria and Transjordan; he had been afflicted by a succession of wars and arbitrary impositions, was desperately short of land and reserve capital, and continued to experience gruelling taxation coupled, where a considerable section of his class was concerned, with an oppressive and humiliating tenurial regime exacerbated by debt and the non-Jewish or pro-Roman attitude of its administrators and landlords. (p. 378)

\section{What happens and can happen to the harvest: An interpretation of Mark 4:3b-8 as a parable of Jesus the Galilean}

The peasants who owned small plots in Judaea and Galilee believed that Yahweh had driven the nations out of Canaan in order to provide Israel with a promised land. The land belonged to Yahweh (Gn 35:12; Lv 25:23), and he alone was responsible for deciding who will dwell there. The land thus was given to them by Yahweh (Ex 6:3, 8; Nm 33:53; Lv 1:21; Dt 17:14), and they had the privilege to work the land as tenants (Lv 25:23). Yahweh promised that the land will yield its fruit and that there will be no hunger ( $\operatorname{Lv} 25: 19)$, and, as long as they obey his commandments, the land will stay in their and their offspring's possession (Gn 48:4; Dt 1:8; 8:1); a land in which they will eat bread without scarcity and will lack nothing (Dt 8:9-10; Ps 85:12). With this belief, the small holders worked the land, the main crops being wheat, maize, olives, figs and grapes, and were able to support a relatively comfortable lifestyle. Seeing as the 'system of tithes and other agricultural offerings had been devised to underline Yahweh's ultimate ownership of the land' (Freyne 2004:46), the peasantry had no problem with the tithes and offerings dedicated to the temple (see e.g. Dt 26:2-3). Outsiders, however, were now enjoying this land. Large amounts of the best agricultural land was owned by Romans, Herod Antipas, the veterans of Herod the Great's armies, the Herodians and the temple elite. The peasantry, on the other hand, who still owned land in most cases had to be content with a shortage of good cultivatable land, minimal land size, thorns and roads at the edge of small fields, and rocky patches because of shortage of plough land (Schottroff 2006:72-73).

Above all, numismatic evidence (read Roman propaganda), especially from the period of Augustus (the so-called aurea aetas [golden age]), communicated that the land belonged to the Caesar, and not to God (see Weissenrieder 2008:501). On 
one coin minted by Augustus, the emperor is depicted as a single ear of corn or a grain bundle with three, four or even six ears of corn (Weissenrieder 2008:504). The propaganda of this coin is made clear by the inscription of KAI $\Sigma$ A[PO $\Sigma$ ] located to the right and left of the image: it is the emperor who is identified with the harvest, and it is the emperor who feeds his subjects (Weissenrieder 2008:504, 506). Another coin, minted by Tiberius (dated $29 \mathrm{CE}$ ), depicts an altar from the imperial cult with grain and wine, which indicates that, according to Roman propganda, the fruit of the land belongs to the rulers of the country (Weissenrieder 2008:508).

According to Sawicki (2000:14), any environment 'expresses the terms in which its residents value their world and negotiate their identity. The landscape is also a mindscape'. Also, if land is like a text (Sawicki 2000:84) and embodies certain social realities (Sawicki 2000:86), ${ }^{35}$ what would have been the 'mindscape' of the first hearers of the Sower, and what social realities does it communicate? What is the implication in the Sower when, for the peasantry, wheat was the staple diet, as well as the main taxable item?

Exactly what do we find in the parable of the Sower when not read as a realistic story about farming and a harvest in 1st century Galilee, but as a realistic depiction of the political, social and economic situation in the time of Jesus?

When Jesus started the parable with the phrase 'a sower went out to sow', what will happen with the harvest to follow was all too clear in the 'mindscape' of the hearers of the parable. Because the elite believed that the harvest belonged to them, tribute will be involved, taxes and rents will have to be paid, and the temple elite will also take their share. Little will be left for the one who is working the land. This, after all, was the social realities of Galilee in 27-30 CE.

As the sower sows, one part of the seed falls on the road

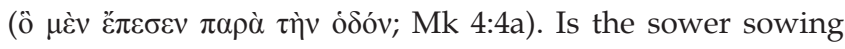
recklessly, or not? Will he plough after sowing or not? This traditional way of interpreting the parable most probably was not part of the mindscape of the first hearers of the parable. As Jones (1995:298) indicated, using agricultural arguments to define the meaning of the parable told by Jesus is missing the point. Seed that falls on the road symbolises that part of the harvest where tax, tribute and rents were paid in kind or, where taxes or rents were exacted in money, peasants had to make use of roads to transport their goods to local markets to sell to wholesale merchants (Hopkins 2002:209). Roads symbolised pressure and exploitation, silos and vaults, trade and markets; aspects which was not part of the mind set of peasants working their lands to provide for family and village. Roads, in short, siphoned wealth out of the hands of peasant farmers. This metaphoric understanding of the

35.See in this regard also the following remark of Brueggemann (1977:2): "Land" continually moves back and forth between literal and symbolic intentions .... A symbolic sense of the term affirms that land is never simply physical dirt but is always physical dirt freighted with social meanings derived from historical experience'. part of the harvest that will go to the elite is strengthened

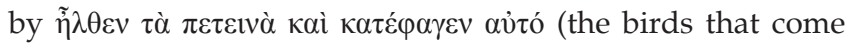
and devour the seed; Mk 4:4b). Birds were not only seen as pesky intruders of cultivated lands and the natural enemies of the sown (Oakman 2008:116), but also served as the primary symbol of Roman military might and concomitantly of Roman imperial ideology (especially the eagle; Peppard 2010:445-447). ${ }^{36}$ Thus, as in 1 Kings 16:3-4 where birds are seen as harbingers of evil (see Blomberg 2004:107), birds spelt evil for the sower. A part of the harvest will be devoured by the elite. ${ }^{37}$

As the sower sows, another part ( $\alpha \lambda \lambda \mathrm{o}$; Mk 4:5) falls on rocky places. Why? Because in some places in the Galilee the soil merely provided a shallow covering for the rocks underneath that the sower did not know and could not see (Snodgrass 2008:155)? Or is it because a farmer is working the land where the abundance of rocks is the result of the exploitation of the peasantry by the elite who expropriated most of the best land? The latter is most probably the case. In Galilee, vast amounts of cultivatable land was owned by the elite and worked by the peasantry to the benefit of the elite. The peasantry, on the other hand, had to be content with a shortage of good cultivatable land. As put by Schottroff (2006):

The parable thus documents not an uneconomical method of planting, but the critical economic situation of the people in Palestine at this time, who had to cultivate the tiniest bits of ground, even if they contained rocky areas. (p. 73)

Thus, according to the parable, a second part of the harvest is also lost, even before sowing starts. This was life for the peasant in 1st century Galilee, looked at from below. Some parts of the harvest that is toiled for, will reap no gain; it already belongs to elite.

Yet, another part of the harvest will also have to be given up. When the sower sows, Jesus tells his hearers, a third part ( $\alpha \lambda \lambda o ;$ Mk 4:7) falls amongst the thorns, and the thorns will grow up and choke the seed, it will yield no grain, at least not for the peasant famer working the land. What is a possible metaphoric reference for the thorns in Mark 4:7? In the Old Testament, thorns are a common metaphor used to describe the wicked (see Scott 1990:354). In Numbers 33:55, for example, the enemies of God's chosen people are described as thorns (see also Ps 118:12; Ezk 2:6), in 2 Samuel 23:6 thorns are used to describe the godless, and in 4 Esdras 16.77 the wicked, because of their sins and iniquities, are also metaphorically described as thorns. For the hearers of the parable, who were these thorns? Most probably the temple elite who also, in terms of tithes and offerings, claimed their part of the harvest. The fact that a part of the seed falls amongst thorns thus reveals its inevitable fate; a part of the harvest will grow, but chocked by the temple elite.

But all is not lost. The Sower is not only about what happens to the harvest, but also about what can happen to the

36.See also Van Eck (2013:245), where the birds in the parable of the Mustard Seed are ironically used as contra-Roman symbol, plundering the base of Roman taxation.

37.This is also the point of view of Herzog (2000:193-195), who interprets the predators (birds) in Mark 4:4 (and the weeds in Mk 4:7) as coded symbols for the Herodian aristocrats that exploit the peasantry through taxes. 
harvest. Many seeds ( $\alpha \lambda \lambda \alpha$; Mk 4:8) fall on good soil, grow and produce a crop that yields a harvest of 30-, 60- and 100fold; a part of the harvest that belongs to the peasant farmer. Why does this part of the seed sown yield such an abundant crop? Because this is what can happen when the harvest, for example, is shared with those who also barely live above a level of subsistence. Large parts of the harvest go to Rome, the Herodian and temple elite, but a part is left that has the potential to make the kingdom visible. How can this be done? Oakman (2012:140) suggests one possibility in stating that the point of the Sower 'may have to do less with the harvest than with the untaxed ... seed available for gleaning'. What Oakman suggests, if interpreted correctly, is the sharing of that part of the harvest that in the end do belong to the peasant that sowed the land. What is left can be used to support other in need by sharing, by giving to everyone who begs from you (Q 6:30), by not asking for goods taken from you (Q 6:30), by doing to others as you would have them do to you (Q 6:31), by lending expecting nothing in return $(Q$ 6:35); in short, by being merciful just as the Father is merciful (Q 6:36). When the 'leftover' yield of the harvest is shared by supporting others in need, the kingdom becomes visible. As such, the kingdom is good news to the poor (Lk 4:18), the place where the hungry will have a feast $(Q 6: 21)$, where those who weep will laugh (Q 6:21), where bread is provided day by day ( $Q$ 11:3), where everyone who asks receives $(Q$ 11:10), and a place where one does not have to worry about what one is going to eat (Q 12:22).

This possible interpretation of Mark 4:8 resonates with Jesus' saying in Mark 10:29-30:

Truly, I say to you, there is no one who has left house or brothers or sisters or mother or father or children or lands, for my sake and for the gospel, who will not receive a hundredfold now in this time, houses and brothers and sisters and mothers and children and lands. (emphasis added) ${ }^{38}$

This saying promises abundance to those who repented and aligned themselves with the good news of Jesus (see Mk 1:15). When this happens, the kingdom of God has arrived.

\section{Concluding remarks}

The parable of the Sower is neither a parable about the obstacles of farming in 1st century Palestine, nor a parable about good and bad soils and hearers of the 'word' (the seed being sown). The Sower is a story about life, suffering, power, taxes, tithes and choices; it depicts the everyday life of the peasantry in 1st century Galilee. The parable not only describes the political, social and economic situation of its first hearers, but also asks its hearers to align themselves with the kingdom of God, and describes what the results of this decision can be. The parable not only describes the 'kingdoms of Rome and the temple elite', but also the kingdom of God. In a world with little choice, the parable gives a vision on how to cope in an exploitative world. In the words of Sawicki (2000):

38. Funk (et al. 1993:93) considers this saying, without the addition of 'for my sake and for the sake of the good news' (Mk 10:29) and 'with persecutions - and in the age to come eternal life' (Mk 10:30), which are considered as a later redactional addition to the text, as an authentic saying of the historical Jesus.
Jesus' first followers knew that there was no escape, no place to go to get away from the civil and personal evils confronting them. They had to figure out how to live in a landscape compromised by colonial oppressions. They would seek and find God's kingdom precisely in the midst of that. (p. 155)

In the Sower, Jesus tells his hearers (who most probably were the peasantry) how to find and live the kingdom in a world where imperial coins depict those in power as the ones who own the harvest and feed their subjects. In the end, the harvest belongs to God, and God is in control of the harvest when shared with others. When shared, everyone will have enough and receive 'hundred fold'.

As such, the Sower envisions a different, and possible, reality for its hearers. This is typical of all the parables of Jesus, as put by Galston (2012):

Unlike an allegory, a parable asks the reader or hearer to imagine a differently organized world with different set values. The aim of the parable is to awaken the hearer in this present world to an altered experience of reality. (p. 80)

\section{Acknowledgements Competing interests}

The author declares that he has no financial or personal relationship(s) that may have inappropriately influenced him in writing this article.

\section{References}

Applebaum, S., 1977, 'Judaea as a Roman province; the countryside as a political and economic factor', Aufstieg und Niedergang der Römischen Welt 2(8), 355-396.

Aviam, M., 2013, 'The Book of Enoch and the Galilean Archeology and landscape', in J.H. Charlesworth \& D.L. Bock (eds.), Parables of Enoch: A paradigm shift, pp. 159-169, Bloomsbury, New York.

Baarslag, D.J., 1940, Gelijkenissen des Heren, 2 de deel, Bosch \& Keuning N.V., Baarn. Barclay, W., 1970, The parables of Jesus, Westminster John Knox Press, Louisville.

Blomberg, C.L., 2004, Preaching the parables: From responsible interpretation to powerful proclamation, Baker Academic, Grand Rapids.

Blomberg, C.L., 2012, Interpreting the parables, 2nd edn., InterVarsity Press, Downers Grove.

Boice, J.M., 1983, The parables of Jesus, Moody Press, Chicago.

Boucher, M.I., 1981, The parables, Michael Glazier Inc., Wilmington. (New Testament Message 7).

Bowker, J.W., 1974, 'Mystery and parable: Mark 4:1-20', Journal of Theological Studies 25, 300-317. http://dx.doi.org/10.1093/jts/XXV.2.300

Brouwer, A.M., 1946, De gelijkenissen, A.W. Sijthoff's Uitgeversmaatschappijy N.V., Leiden.

Brueggemann, W., 1977, The land: Place as gift, promise, and challenging biblical faith, Fortress Press, Philadelphia.

Bugge, C.A., 1903, Die Haupt-Parabeln Jesu, J. Rickersche Verlagsbuchhandlung, Griessen.

Bultmann, R., 1968, History of the synoptic tradition, transl. J. Marsh, Blackwell, Oxford.

Cadoux, A.T., 1930, The parables of Jesus: Their art and use, James Clarke, London. Carlston, C.E., 1975, The parables of the triple tradition, Fortress Press, Philadelphia.

Charlesworth, J.H. (ed.), 1983, The Old Testament pseudepigrapha: Apocalyptic literature and testaments, vol. 1, Hendrickson Publishers, Peabody.

Charlesworth, J.H., 2013, 'The date and provenience of the Parables of Enoch', in J.H. Charlesworth \& D.L. Bock (eds.), Parables of Enoch: A paradigm shift, pp. 37-57, Bloomsbury, New York.

Crossan, J.D., 1973, In parables: The challenge of the historical Jesus, New York, Harper \& Row

Crossan, J.D., 2012, The power of parable: How fiction by Jesus became fiction about Jesus, SPCK, London.

Dewey, A.J., 1980, Markan public debate: Literary technique, concentric structure, and theology in Mark, Scholars Press, Chico. (SBLDS 48).

Dodd, C.H., 1961, The parables of the kingdom, Charles Scribner's Sons, New York. 
Donahue, J.R., 1988, The gospel in parable: Metaphor, narrative and theology in the Synoptic gospels, Fortress Press, Philadelphia.

Dronsch, K, 2007, 'Vom Fruchtbringen (Sämann mit Deutung) - Mk 4,3-9(1012.)13-20, (Mt 13,3-9.18-23 / Lk 8,5-8.11-15 / EvThom 9 / Agr 220)', in R. Zimmermann (Hrsg.), Kompendium der Gleichnisse Jesu, pp. 297-316 Gütersloher Verlagshaus, Munich.

Drury, J., 1985, The parables in the gospels: History and allegory, Crossroad, New York.

Dwight, J., 1982, The parables of Jesus: Lessons in life from the master teacher, Kregel Publications, Grand Rapids.

Edwards, J.R., 2002, The gospel according to Mark, William B. Eerdmans Publishing Company, Grand Rapids.

Evans, C.A., 1989, To see and not perceive: Isaiah 6:9-10 in early Jewish and Christian interpretation, Sheffield Academic Press, Sheffield. (JSOTSup 64).

Fitzmyer, J.A., 1985, The gospel according to Luke X-XXIV, vol. II, Doubleday, New York.

Flusser, D., 1981, Die rabbinische Gleichnisse und der Gleichniserzähler Jesus, Band 1: Das wesen der Gleichnisse, Peter Lang, Bern.

Freyne, S., 1980, Galilee from Alexander the Great to Hadrian 323 B.C.E. to 135 C.E.: A study of Second Temple Judaism, Michael Glazier, Inc., Delaware.

Freyne, S., 2004, Jesus, a Jewish Galilean: A new reading of the Jesus-story, T\&T Clark, London.

Fuchs, E., 1960, Zur Frage nach dem historischen Jesus, JCB Mohr, Tübingen.

Funk, R.W., Hoover, R.W. \& The Jesus Seminar, 1993, The five gospels: The search for the authentic words of Jesus, Macmillan, New York.

Galston, D., 2012, Embracing the human Jesus: A wisdom path for contemporary Christianity, Sale, Polebridge Press.

Garland, D.E., 1993, Reading Matthew: A literary and theological commentary on the First Gospel, Crossroad, New York.

Garnet, P., 1983, 'The parable of the sower: How the multitudes understood it', in E.J. Furcha (ed.), Spirit within structure, pp. 39-45, Pickwick, Allison Park.

Gladden, W., 1883, 'Things new and old', in A.H. Smythe (ed.), Discourses of Christian truth and life, pp. 3-27, Columbus, Óhio.

Groenewald, E.P., 1973, In gelykenisse het Hy geleer, N.G. Kerk-Uitgewers, Kaapstad.

Guelich, R.A., 1989, Mark, Word Books, Dallas. (World Biblical Commentary, vol. 34a).

Hedrick, C.W., 2004, Many things in parables: Jesus and his modern critics, Westminster John Knox Press, London.

Henaut, B.W., 1993, Oral tradition and the gospels: The problem of Mark 4, Sheffield Academic, Sheffield. (JSNTSup 82).

Hopkins, K, 2002, 'Rome, taxes, rents and trade', in W. Scheidel \& S. Von Reden (eds.), The ancient economy, pp. 190-230, Edinburg University Press, Edinburgh. (Edinburgh readings on the ancient world).

Herzog, W.R., 2000, Jesus, justice, and the reign of God: A ministry of liberation, Westminster John Knox Press, Louisville.

Horsley, R.A., 1996, Archeology, history, and society in Galilee: The social context of Jesus and the rabbis, Trinity Press International, Valley Forge.

Horsley, R.A., 2009, Covenant economics: A biblical vision of justice for all, Westminster John Knox Press, Louisville.

Hultgren, A.J., 2000, The parables of Jesus: A commentary, William B. Eerdmans Publishing Company, Grand Rapids.

Hunter, A.M., 1960, Interpreting the parables, Westminster Press, Philadelphia

Jeremias, J., 1972, The parables of Jesus, SCM Press Ltd, London. http://dx.doi. org/10.1017/S0028688500000977

Jeremias, J., 1966, 'Palästinakundliches zum Gleichnis vom Saemann', New Testament Studies 13, 48-53.

Jones, G.V., 1964, The art and truth of the parables, SPCK, London.

Jones, I.H., 1995, The Matthean parables: A literary and historical commentary, E.J. Brill, Leiden. (Supplements to Novum Testamentum, vol. LXXX). http://dx.doi. org/10.1163/9789004267268

Jones, P.R., 1999, Studying the parables, Smyth \& Helwys, Macon.

Kilgallen, J.J., 2008, Twenty parables of Jesus in the gospel of Luke, Editrice Pontificio Instituto Biblico, Rome. (Subsidia Biblica 32).

Kissinger, W.S., 1979, The parables of Jesus: A history of interpretation and bibliography, The Scarecrow Press, Metuchen.

Kistemaker, S.J., 1980, The parables: Understanding the stories Jesus told, Baker Books, Grand Rapids.

Klauck, H-J., 1978, Allegorie und Allegorese in synoptishen Gleichnistexten, Aschendorf, Münster. (NTAbh 13).

Lambrecht, J., 1983, Once more astonished: The parables of Jesus, Crossroad, New York.

Liebenberg, J., 2000, The language of the kingdom and Jesus: Parable, aphorism, and metaphor in the sayings material common to the Synoptic tradition and the and metaphor in the sayings material comm
Gospel of Thomas, Walter de Gruyter, Berlin.

Linnemann, E., 1980, Parables of Jesus: Introduction and exposition, 5th edn., transl. J. Sturdy, SPCK, London.

Lockyer, H., 1963, All the parables of the Bible, Zondervan, Grand Rapids.

Lohfink, G., 2012, Jesus of Nazareth: What he wanted, who he was, transl. L.M. Maloney, Liturgical Press, Collegeville.

Luz, U., 1990, Das Evangelium nach Matthäus, vol. 2, Mt 8-17, Benziger Verlag, Zurich. (EKKNT 1/2)

Maldonatus, J., 1888, A commentary on the holy gospels: S. Matthew's gospel, chapters I to IXV, transl. J. Davie, John Hodges, London.
Malina, B.J. \& Rohrbaugh, R.L., 2003, Social science commentary on the Synoptic gospels, 2nd edn., Fortress Press, Minneapolis.

Marcus, J.B., 1986, The mystery of the kingdom of God, Scholars Press, Atlanta. (SBLDS 90). Marcus, J.B., 2000, Mark 1-8: A new translation with introduction and commentary, Doubleday, New York. (AB 27).

Marshall, I.H., 1978, The gospel of Luke, Paternoster Press, Exeter.

Mclver, R.K., 1994, 'One hundred-fold yield - Miraculous of mundane? Matthew 13.8 23; Mark 4.8, 20; Luke 8.8', New Testament Studies 40, 606-608. http://dx.doi. org/10.1017/S0028688500024024

Morgan, G.C., 1953, The parables and metaphors of our Lord, Marshall, Morgan \& Scott Ltd., London.

Nolland, J. 1989, Luke 1-9:20, Dallas, Word. (WBC 35A).

Oakman, D.E., 1986, Jesus and the economic questions of his day, Edwin Mellen Press, New York.

Oakman, D.E., 2008, Jesus and the peasants, Cascade Books, Eugene. (Matrix: The Bible in Mediterranean context 4).

Oakman, D.E., 2012, The political aims of Jesus, Fortress Press, Minneapolis.

Painter, J., 1997, Mark's gospel: Worlds of conflict, Routledge \& Kegan Paul, London. (New Testament Readings).

Patterson, S.J., Bethge, H-G. \& Robinson, J.M., 2011, The fifth gospel: The gospel of Thomas comes of age, T\&T Clark, New York.

Payne, P.B, 1978, 'The order of so wing and ploughing in the parable of the sower', New Testament Studies 25, 123-129. http://dx.doi.org/10.1017/S0028688500001247

Peppard, M., 2010, 'The eagle and the dove: Roman imperial sonship and the baptism of Jesus', New Testament Studies, 56, 431-451. http://dx.doi.org/10.1017/ S0028688510000159

Pesch, R., 1984, Das Markusevangelium, vol. 1, Herder, Freiburg. (HTKNT 2).

Peters, D., 1997, 'Vulnerable promise from the land', in V.G. Shillington (ed.), Jesus and his parables: Interpreting the parables of Jesus today, pp. 69-84, T\&T Clark, Edinburgh.

Reid, B.E., 2001, Parables for preachers: The gospel of Matthew, The Liturgical Press, Collegeville.

Sawicki, M., 2000, Crossing Galilee: Architectures of contact in the occupied land of Jesus, Trinity Press International, Pennsylvania.

Schippers, R., 1962, Gelijkenissen van Jezus, J.H. Kok N.V, Kampen.

Schottroff, L., 2006, The parables of Jesus, transl. L.M. Maloney, Fortress Press, Minneapolis.

Schweitzer, A., 1963, The kingdom of God in the teaching of Jesus, Westminster Press, Philadelphia.

Scott, B.B., 1990, Hear then the parable: A commentary on the parables of Jesus, Fortress Press, Minneapolis.

Snodgrass, K.R., 2008, Stories with intent: A comprehensive guide to the parables of Jesus, William B. Eerdmans Publishing House, Grand Rapids.

Stein, R.H., 1981, An introduction to the parables of Jesus, The Westminster Press, Philadelphia.

Stiller, B.C., 2005, Preaching parables to postmoderns, Minneapolis, Fortress Press. (Fortress Resources for Preaching).

Timmer, J., 1990, The kingdom equation: A fresh look at the parables of Jesus, CRC Publications, Grand Rapids.

Tolbert, M.A., 1989, Sowing the gospel: Mark's gospel in literary-historical perspective, Fortress Press, Minneapolis.

Torrance, D.W. \& Torrance, T.F. (eds.), 1972, Calvin's commentaries: A harmony of the gospels Matthew, and Luke, vol. 3, transl. A.W. Morrison, Saint Andrews Press, Edinburgh.

Van Eck, E., 2013, 'When kingdoms are kingdoms no more: A social-scientific reading of the Mustard Seed (Lk 13:18-19)', Acta Theologica 33(2), 226-254. http:// dx.doi.org/10.4314/actat.v33i2.13

Via, D.O., 1967, The parables: Their literary and existential dimension, Fortress Press, Philadelphia.

Von Harnack, A., 1901, What is Christianity? Lectures delivered in the University of Berlin during the winter-term 1899-1900, transl. T.B. Saunders, viewed 25 January 2014, from https://archive.org/details/whatischristian01saungoog

Weder, H., 1984, Die Gleichnisse Jesu als Metaphern: Traditions- und redaktionsgeschichtliche Analysen und Interpretationen, Vandenhoeck \& Ruprecht, Göttingen. (FRLANT 120).

Weiss, J., 1900, Die Predicht Jesu vom Reiche Gottes, Vandenhoeck \& Ruprecht, Götiingen.

Weissenrieder, A., 2008, 'Didaktik der Bilder: Allegorie und Allegorese am Beispiel von Mk 4, 3-20', in R. Zimmermann \& G. Kern (Hrsg.), Hermeneutik der Gleichnisse Jesu: Methodische Neuansätze zum Verstehen urchristlicher Parabeltexte, pp. 494-520, Mohr Siebeck, Tübingen. (WUNT 238).

Wenham, D., 1974, 'The interpretation of the parable of the sower', New Testament Studies 20, 299-319. http://dx.doi.org/10.1017/S002868850001482X

Wenham, D., 1989, The parables of Jesus: Pictures of a revolution, Hodder \& Stoughton, London. (The Jesus Library).

Westermann, C., 1990, The parables of Jesus in the light of the Old Testament, transl. F.W. Golka \& A.H.B. Logan, T\&T Clark, Edinburgh.

White, K.D., 1964, 'The parable of the sower', Journal of Theological Studies 15, 300 307. http://dx.doi.org/10.1093/jts/XV.2.300

Wright, N.T., 1996, Christian origins and the question of God, vol. 2: Jesus and the victory of God, Fortress Press, Minneapolis. 